\title{
PENGALAMAN SUAMI BERSUKU MELAYU DALAM MENDAMPINGI ISTRI BERSALIN
}

\author{
Elisia Elfina ${ }^{1}$, Ari Pristiana Dewi ${ }^{2}$, Reni Zulfitri ${ }^{3}$ \\ 1,2,3PSIK Universitas Riau \\ Program Studi Ilmu Keperawatan Universitas Riau Jalan Pattimura No 9 Gedung G Pekanbaru Riau \\ Kode Pos 28131 Indonesia \\ Telepon 081275350931 email Elfinaelisia@yahoo.com
}

\begin{abstract}
Abstrak
Penelitian ini bertujuan untuk mengeksplorasi pengalaman suami bersuku Melayu dalam mendampingi istri bersalin. Metode penelitian adalah kualitatif dengan pendekatan fenomenologi, yang dilakukan di Puskesmas Kuok Kabupaten Kampar Kecamatan Kuok, yang melibatkan 4 partisipan. Partisipan dipilih dengan menggunakan teknik purposive sampling. Pengumpulan data menggunakan wawancara semi-struktur dengan pedoman wawancara. Hasil penelitian menemukan ada 4 tema yaitu: (1) perasaan suami saat mendampingi istri bersalin yaitu perasaan positif (senang, terharu dan bahagia) dan perasaan negatif (cemas, takut, degdegan dan sedih), (2) cara suami mengatasi perubahan psikologi saat mendampingi istri bersalin yaitu denganmelakukan teknik relaksasi nafas dalam dan kegiatan spiritual seperti berserah diri, berdoa dan berzikir dengan yang Maha Kuasa,(3) dukungan suami saat mendampingi istri bersalin terdiri dari dukungan fisik yaitu memegang tangan, mengelus rambut, kepala, perut dan memijit punggung istrinya dan dukungan informatif yaitu motivasi berupa kata-kata semangat, berzikir dan istighfar menyebut nama Allah, (4) alasan suami mendampingi istri selama proses persalinan karena adanya keinginan dan kesadaran dari diri pasrtisipan itu sendiri seperti memiliki kewajiban dan tanggung jawab untuk mendampingi saat persalinan. Hasil penelitian ini diharapkan agar para suami selalu mendampingi istri selama proses persalinan karena dukungan yang diberikan oleh suami dapat memberikan kenyamanan pada istri saat bersalin.
\end{abstract}

Kata kunci: mendampingi, pengalaman suami.

\begin{abstract}
This research aims to explore the experiences of Malay husbands in assisting the wives to give birth. The method of research is qualitative with a phenomenology approach, the research was conducted in Puskesmas Kuok Kabupaten Kampar Kecamatan Kampar, involving 4 participants. Participants were selected using purposive sampling technique. Data collection using semi-structured interviews with interview guidance. The results of study found there are 4 main themes: (1) the feelings of the husband while accompanying the wife of childbirth are positive feelings (happy, touched and happy) and negative feelings (anxiety, fear and sad ), (2) when accompanied by the wife of childbirth that is by doing relaxation of breath techniques and spiritual activities such as surrender, pray and zikir with the Almighty, (3) the support of the husband when accompanied by the birth wife consists if physical support that is holding hands, striked hair, head, stomach, and massage the back of his wife and informative support that is motivation in the form of words of spirit, zikir and istighfar mention the name of Allah, (4) reason husbands accompanying wife during delivery process because of desire and consciousness of self participants it self like have obligation and responsibility to accompany delivery process. The results of this study is expected that the husband is always accompanying the wife during the process of childbirth because the support provided by the husband can provide comfort to the wife during childbirth.
\end{abstract}

Keyword: Accompany, Husband experience.

\section{PENDAHULUAN}

Kehamilan adalah proses fertilisasi dari spermatozoa dan ovum sampai partus, lama kehamilan normal sekitar 280 hari (40 minggu) yang dihitung dari hari pertama haid terakhir. Ditinjau dari usia kehamilan, kehamilan dapat dibagi dalam 3 bagian, yaitu trimester I (0-12 minggu), trimester II (12-28 
Elisia Elfina ${ }^{1}$, Ari Pristiana Dewi ${ }^{2}$, Reni Zulfitri ${ }^{3}$, Pengalaman Suami Bersuku Melayu dalam mendampingi Istri Bersalin

minggu $)$ trimester III $\quad(28-40 \quad$ minggu $)$

(Saminem, 2009).

Trimester pertama merupakan awal trimester yang menimbulkan berbagai respon pada ibu hamil. Respon yang paling berpengaruh pada ibu adalah mual dan muntah.Hampir 50-90\% wanita hamil mangalami mual (nausea) dan muntah (emesis gravidarum). Pada trimester kedua, rasa mual dan muntah yang dialami pada trimester pertama sudah mulai berkurang.Perut ibu sudah kelihatan membesar danibu mulai merasa senang dengan kehadiran janin dalam rahimnya. Trimester tiga merupakan saat-saat yang paling mendebarkan bagi ibu hamil, terutama saat mendekati proses persalinan. Trimester ini menyebabkan tingginya kecemasan pada ibu hamil terutama pada ibu anak pertama (Saminem, 2009).

Kecemasan yang dialami ibu primigravida menjelang persalinan pertamanya adalah kecemasan dalam kelancaran saat proses persalinan, perkembangan janin dalam rahim, kemungkinan komplikasi yang terjadi saat persalinan dan nyeri saat persalinan. Ibu primigravida juga mengalami rasa khawatir, was-was, gelisah dan takut dalam menghadapi kehamilannya (Anggraeni, Sumarni, \& Agustina, 2014).

Persiapan ibu menjelang persalinan yaitu menghindari kecemasan, ketakutan, bersikap tenang dan meminta dukungan suami. Dukungan suami yang diharapkan istri berupa dukungan moral dan materil. Dukungan moral seorang suami pada istrinya sangat dibutuhkan. Suami dianjurkan untuk memberikan dukungan yang lebih besar kepada istrinya termasuk saat proses persalinan (Dagun, 2002). Suami memberikan dukungan moril yang baik saat periksa kehamilan, persiapan persalinan dan saat proses persalinan istri (Mahmudah \& Barokah, 2016).

Kehadiran suami saat proses persalinan sangat bernilai positif pada istri. Suami yang hadir dapat memberikan dukungan seperti melakukan pijatan ringan dibagian punggung untuk meredakan sakit istrinya, mengukur lamanya waktu kontraksi, menyampaikan pesan istrinya kepada perawat dan dokter, memberikan perhatian dan motivasi (Dagun, 2002).

Dukungan yang diberikan oleh suami dapat memberikan kenyamanan pada saat bersalin. Istri yang mendapatkan dukungan dari suami akan menimbulkan efek positif terhadap hasil persalinan yaitu dapat mengurangi rasa sakit saat bersalin, mengurangi ketegangan ibu hamil dan memperbaiki status emosional sehingga memperbaik proses persalinan (Primasnia, Wagiyo, \& Elisa, 2013).

Hasil penelitian yang dilakukan terhadap budaya di Propinsi Papua Kabupaten Mimika bersuku Amungme. Budaya bukan hanya menjadi suatu hambatan terhadap proses persalinan, namun budaya dapat memberikan dukungan positif terhadap proses persalinan. Penduduk Amungme meyakini bahwa asap kayu bakar dapat membawa kekuatan bagi 
orang yang sakit atau lemah termasuk ibu yang sedang melahirkan. Dalam penelitian ini suami memberikan dukungan dalam proses persalinan istrinya dengan menghidupkan dan menjaga api kayu bakar selalu hidup dan asapnya bertiup mengarah ke tempat ibu. Ibu berusaha mendapatkan kekuatan dengan menghirup asap sebanyak-banyaknya, karena menurut keyakinan budaya mereka asap membawa kekuatan dari roh untuk melancarkan persalinan (Alwi, 2007).

Perempuan Jawa selama proses persalinan juga mendapatkan dukungan dari suami, ibu atau keluarga. Bagi orang Jawa yang memeluk agama islam, suami sangat diharapkan untuk hadir saat proses persalinan. Suami yang hadir selama proses persalinan sebagai penyemangat dan berkewajiban untuk menyuarakan adzan pada bayinya (Ambarwati, 2015).

Dukungan yang diberikan oleh suami kadang tidak bisa terlaksana dengan baik.Hal ini dipengaruhi oleh adanya perubahan psikologi suami saat menghadapi persalinan yaitu kecemasan. Kecemasan suami disebabkan olehfaktor usia, status kesehatan, pendidikan, pengetahuan, perencanaan persalinan, kebijakan dari rumah sakit, pengalaman persalinan istri sebelumnya, status kesehatan, status sosial ekonomi dan latar belakang budaya (Misrawati, Setyowati \& Afiyanti (2006)., Nurjanah \& Indrawati (2013).

Kecemasan yang dialami suami lebih tinggi dari pada kecemasan yang di alami oleh istrinya. Kecemasan yang dialami oleh suami yaitu cemas akan biaya persalinan, perlengkapan bayi yang harus dipenuhi, dan nutrisi yang cukup untuk anak dan istrinya (Dagun, 2002). Tingkat kecemasan yang sering dialami suami saat mengahadapi persalinan istri adalah merasa tegang sebanyak 90\%, sukar konsentrasi sebanyak 91,1\% dan mengalami gelisah sebanyak 74,4\% (Nurjanah \& Indrawati, 2013).

Munurut penelitian yang dilakukan oleh Misrawati, Setyowati, dan Afiyanti (2006), Nurjanah dan Indrawati (2013), hambatan yang didapatkan suami saat mendampingi persalinan adalah suami mengalami kecemasan yang di pengaruhi oleh latar belakang dari budaya. Namun berdasarkan dari hasil beberapa penelitian yang didapatkan tentang latar belakang budaya.Budaya tidak menjadi suatu hambatan dalam persalinan istri. Budaya dapat memberikan dampak positif saat persalinan istri.Salah satunya penelitian yang dilakukan di provinsi Papua Kabupaten Mimika yang memiliki keunikan dalam budayanya.

Budaya merupakan suatu kebiasaan yang diwariskan dari generasi ke generasi berikutnya. Budaya adalah hasil dari pemikiran, kegiatan, dan hasil karya manusia yang akan membentuk pola atau kebiasaan dalam proses kehidupan manusia (Sutrisno \& Putranto, 2005). Budaya memiliki karakteristik yang berbeda-beda termasuk budaya Melayu.

Budaya Melayu memiliki suatu tradisi yang dilakukan setelah menikah, pasangan 
Elisia Elfina ${ }^{1}$, Ari Pristiana Dewi ${ }^{2}$, Reni Zulfitri ${ }^{3}$, Pengalaman Suami Bersuku Melayu dalam mendampingi Istri Bersalin

suami istri dapat menumpang di kediaman kerabat istri (matrilokal) sampai mereka mampu membangun rumah sendiri (Melalatoa, 1995). Lelaki Melayu yang sudah menikah bertanggung jawab dalam mencari nafkah, melindungi anak dan istrinya, sebagai pengayom dalam keluarga, sehingga suami harus memiliki sifat tegas, bijaksana, dan disiplin dalam mengasihi keluarganya. Suami juga memiliki peran dalam berpartisipasi mengasuh dan mendidik anaknya untuk menjadi anak yang baik sesuai dengan ajaran agama Islam (Rahman\& Yusuf, 2012).

Hal ini juga sesuai dengan hasil wawancara yang dilakukan kepada Sekretaris Umum Lembaga Adat Melayu Provinsi Riau bapak M. Nasir Penyalai mengatakan bahwa karakteristik budaya Melayu berpedoman dengan agama Islam karena budaya Melayu identik dengan agama Islam. Karakteristik lelaki budaya Melayu adalah bersifat penyayang dan bertanggung jawab. Lelaki Melayu yang sudah menikah bertanggung jawab dalam mencari nafkah dan mendampingi istrinya selama proses persalinan. Kehadiran suami saat proses persalinan akan membuat istri menjadi lebih semangat, mengurangi rasa takut dan mengurangi rasa sakit yang dialami istri saat proses bersalin. Peran suami saat proses persalinan istri adalah suami sebagai penyemangat, berkewajiban untuk menyuarakan adzan pada bayinya dan selalu berdoa kepada Allah untuk kelancaran proses persalinan. Dalam adat budaya Melayu, orang tua berperan sebagai penasehat, sumber informasi tentang peran selama melahirkan, proses melahirkan dan setelah melahirkan. Namun pendapat dari Sekretaris Umum Lembaga Adat Melayu Provinsi Riau bertentangan dengan hasil studi pendahuluan yang dilakukan.

Berdasarkan survei pendahuluan dari suami bersuku Melayu yang mendampingi istri bersalin di Kabupaten Kampar Kecamatan Kuok dengan metode wawancara terdapat suatu perbedaan pendapat. Hasil studi pendahuluan yang dilakukan suami mengatakan ingin ikut serta menemani istri dalam proses persalinan, namun tidak diberi izin oleh ibu mertuanya, karena menurut mertuanya kehadiran suami saat mendampingi istri bersalin anaknya tidak mau lahir, karena anak masih malu untuk bertemu dengan ayahnya dan proses persalinan menjadi lama atau persalinan tidak maju-maju. Hal ini didasarkan atas kebiasaan perilaku leluhur dan orang tua mereka yang sudah terlaksanakan sejak dahulu kala sampai sekarang. Melihat adanya perbedaan pendapat tersebut dan budaya memberikan dampak positif didalam proses persalinan maka perlu diteliti lebih lanjut tentang "Pengalaman suami bersuku Melayu dalam mendampingi istri bersalin"

\section{METODOLOGI PENELITIAN}

Penelitian ini dilakukan di Puskesmas Kuok Kabupaten Kampar Kecamatan Kuok. Penelitian ini dimulai dari bulan Februari 2016 
sampai dengan Juli 2017. Penelitian ini merupakan sebuah penelitian kualitatif dengan pendekatan fenomenologi. Metode penelitian merupakan strategi perencanaan penelitian dalam mengidentifikasi permasalahan sebelum perencanaan akhir pengumpulan data yang digunakan untuk mengidentifikasi struktur dimana penelitian itu dilaksanakan. Desain penelitian adalah keseluruhan dari perencanaan untuk menjawab pertanyaan penelitian dan mengantisipasi beberapa kesulitan yang mungkin timbul selama proses penelitian (Sugiyono, 2012).

Populasi dalam penelitian ini adalah suami bersuku Melayu yang memiliki pengalaman dalam mendampingi istri bersalin di Puskesmas Kuok. Jumlah partisipan dalam penelitian kualitatif ini yaitu sebanyak 4 orang partisipan. Partisipan ini dipilih menggunakan metode purposive sampling. Purposive sampling dilakukan untuk memilih partisipan yang sesuai dengan tujuan penelitian.Peneliti dalam penelitian ini menetapkan kriteria tambahan dalam pemilihan partisipan yang dikenal dengan istilah kriteria inklusi. Kriteria inklusi dalam penelitian ini yaitu Suami bersuku Melayu yang mendampingi istri bersalin anak pertama dengan usia bayi <2 minggu dan Suami bersuku Melayu yang mampu berkomunikasi dengan baik.

\section{HASIL PENELITIAN}

\section{A. Karakteristik Partisipan}

Partisipan yang telah ikut serta dalam penelitian ini adalah sebanyak 4 (empat) orang suami yang bersuku Melayu mendampingi istri bersalin anak pertama di Puskesmas Kuok Kabupaten Kampar Kecamatan Kuok dengan rentang usia suami 21 sampai 27 tahun dan bersuku Melayu. Pendidikan terakhir suamiadalah SMA dan S1. Seluruh partisipan beragama Islam, mendampingi istri dalam persalinan normal dan memiliki bayi berusia 1 sampai 13 hari. Karakteristik partisipan dijabarkan pada tabel 1 .

Tabel 1.

Karakteristik partisipan

\begin{tabular}{|c|c|c|c|c|}
\hline Kategori & Usia & $\begin{array}{c}\text { Tingkat } \\
\text { Pendidikan }\end{array}$ & Pekerjaan & $\begin{array}{l}\text { Usia } \\
\text { Anak }\end{array}$ \\
\hline P1 & $\begin{array}{c}27 \\
\text { Tahun }\end{array}$ & $\begin{array}{c}\text { S1 } \\
\text { Perikanan }\end{array}$ & $\begin{array}{c}\text { Dinas } \\
\text { Perikanan }\end{array}$ & $\begin{array}{c}13 \\
\text { Hari }\end{array}$ \\
\hline $\mathrm{P} 2$ & $\begin{array}{c}24 \\
\text { Tahun }\end{array}$ & SMA & Satpam & $\begin{array}{c}1 \\
\text { Hari } \\
\end{array}$ \\
\hline P3 & $\begin{array}{c}21 \\
\text { Tahun }\end{array}$ & SMA & Wiraswasta & $\begin{array}{c}2 \\
\text { Hari }\end{array}$ \\
\hline $\mathrm{P} 4$ & $\begin{array}{c}23 \\
\text { Tahun }\end{array}$ & SMA & Wiraswasta & $\begin{array}{c}5 \\
\text { Hari }\end{array}$ \\
\hline
\end{tabular}

\section{B. Analisis Tematik}

Hasil penelitian ini menghasilkan 4 (empat) tema yang memberikan gambaran fenomena tentang pengalaman suami bersuku Melayu dalam mendampingi istri bersalin yaitu: (1) perasaan suami saat mendampingi istri bersalin, (2) cara suami mengatasi perubahan psikologi saat mendampingi istri bersalin, (3) dukungan suami saat mendampingi istri bersalin, (4) alasan suami mendampingi istri selama proses persalinan.

\section{Perasaan suami saat mendampingi istri bersalin}

Hasil analisa data dari transkip data yang sudah dilakukan kepada partisipan didapatkan adanya tema tentang perasaan suamisaat mendampingi istri bersalin, dalam tema ini partisipan menyatakan perasaan positif saat 
Elisia Elfina ${ }^{1}$, Ari Pristiana Dewi ${ }^{2}$, Reni Zulfitri ${ }^{3}$, Pengalaman Suami Bersuku Melayu dalam mendampingi Istri Bersalin

mendampingi istri bersalin.Perasaan positif partisipan dapat dilihat dariperasaan senang, terharu dan bahagia saat mendampingi istri bersalin. Pernyataan ini dapat didukung oleh ungkapan partisipan sebagai berikut:

"Rasanya tu campur aduk dek, senang juga ada, terharu juga ada...”(P2-9)

“...jadi terharu, bahagia, dan senang lah pokoknya karena telah melahirkan seorang anak yang telah membuat keluarga menjadi lebih bahagia lebih lengkap, ceria..."(P4-16)

Selain itu, partisipan juga mengalami perasaan negatif saat mendampingi istri bersalin.Perasaan negatif yang dirasakan oleh partisipan adalah perasaan yang buruk atau perasaan yang tidak menyenangkan.Partisipan dalam penelitian ini menyatakan bahwa perasaan negatif mereka saat mendampingi istri bersalin adalah cemas,takut, deg-degan dan sedih. Hal ini sesuai dengan ungkapan partisipan sebagai berikut:

“...apalagi anak pertama cemas juga ada gitu...”(P1-1)

"Ya cukup lama lah istri abang menunggu pembukaan selanjutnya.Disitu abang merasa cemas aa istri abang udah nangis karena gak sanggup nahan sakit..."(P29).

"Aaa pengalaman saya ya jelas saat itu saya merasa deg-degan, kemudian saya cemas, takut dan sedihlah juga"(P3-12).

"Waktu itu, abang merasakan takut sekali dengan keselamatan istri abang saat itu kan, waktu itu istri abang udah merasakan sakit tak tertahan..."(P4-17).
2. Cara suami mengatasi perubahan psikologi saat mendampingi istri bersalin

Hasil analisa transkip data dalam penelitian ini, peneliti juga menemukan adanya cara yang dilakukan partisipan dalam mengatasi perubahan psikologi saat mendampingi istri bersalin. Cara partisipan untuk mengatasi perubahan psikologi seperti perasaan cemas, takut, deg-degan dan sedih selama mendampingi istri bersalin, didapatkan duacarayaitudengan melakukan kegiatan spiritual dan teknik relaksasi nafas dalam. Kegiatan-kegiatan spiritual yang dilakukan partisipan yaitu: berserah diri, berdoa dan berzikir kepada yang Maha Kuasa. Hal ini sesuai dengan ungkapan partisipan sebagai berikut:

“...harus dilawan lah rasa takut dan cemas nya itu, walaupun kan banyak darah tu, namanya juga melahirkan kan, tapi ya namanya juga mau melahirkan, istri mau melahirkan anak ya harus dikuat-kuatkan lah. Berserah diri aja, istilah ya berdoa, biar istri melahirkannya itu lancar..."(P1-3)

"Aaa saya berdoa kemudian minta kepada Allah SWT karena saya yakin bahwa dialah yang bisa membantu hambanya dan hanya dialah yang tau apa yang terbaik untuk hambanya.Kemudian dan saya juga selalu berzikir didalam hati, berikan lah yang terbaik untuk anak, istri saya nantinya."(P3-13)

"Cara mengatasi semua perasaan itu yang jelas abang bersikap tenang, berusaha untuk tidak panik, berserah diri dengan banyak berdoa, dan sholat sunah..."(P4-19) 
Selain dari pada itu, partisipan juga menyatakan untuk mengatasi perubahan psikologi yang dialami selama mendampingi istri bersalin yaitu dengan tarik nafas dalam.Tarik nafas dalam yang dilakukan partisipan dapat membuat partisipan menjadi lebih tenang. Hal ini didapatkan dariungkapan penyataan partisipan sebagai berikut:

"Ya abang cuman tarek nafas dalam aja gitu, aaa tidak mungkin lah kita tunjukin ke istri kita kalau kita takutkan..."(P2-10)

“...terus tarik nafas dalam juga abang biar tetap tenang gitu kan...”(P4-19)

\section{Dukungan suami saat mendampingi istri bersalin}

Hasil analisa data dari tarnskip data yang didapatkan oleh peneliti, partisipan dalam penelitian ini juga memberikan dukungan kepada istrinya saat mendampingi istrinya selama proses persalinan. Dukungan yang diberikan partisipan kepada istrinya berupa dukungan yang berdampak positif terhadap perkembangan proses persalinan istri. Bentuk dukungan yang diberikan partisipan adalah dukungan fisik.Dukungan fisik yang diberikan yaitu seperti memegang tangan, mengelus rambut, kepala, perut dan memijit punggung istrinya.Hal ini sesuai dengan ungkapan partisipan sebagai berikut:

“...mengelus-ngelus rambutnya, saya pegang tangan istri saya...”(P1-2)

“...karena istri abang merasakan kesakitan tangan abang digenggamnya gitu, selama tangan abang digenggamnya kuat-kuat sampai sampai tangan abang ni sampai basah..."(P2-7)
“...Saya juga memijit punggung istri saya...”(P3-14)

“...dan juga abang mengelus kepalanya, memegang tangannya dan juga abang mengelus-ngelus perut istri abang dan abang juga membantu kakak memberikan posisi yang nyaman untuk nya..."(P4-18)

Selain dari itu, partisipan juga memberikan dukungan informatif kepada istrinya. Dukungan informatif yang diberikan partisipan adalah memberikan motivasi berupa kata-kata semangat, berzikir dan istighfar menyebut nama Allah, seperti yang dinyatakan oleh partisipan sebagai berikut:

“...terus berikan semangat, dengan kata-kata semangat ya ini pasti berakhir, nantik anak kita juga akan lahir jadi semangat... "(P1-2)

"Mmmm tindakannya ya jadi abang berikan motivasi, kata-kata semangat, trus abang selalu bilang kepada istri abang untuk banyak istighfar saat dia merasakan kesakitan..."(P2-7)

"...kemudian saya juga membisikkan di telinga istri saya kata-kata semangat, kemudian menyuruh istri saya banyak berzikir dan menyebut nama Allah..."(P3-14)

“...yang jelas abang berikan semangat, abang berikan motivasi, dan menyuruh istri abang untuk banyak istighfar agar dipermudahkan dalam proses persalinannya..."(P4-18)

\section{Alasan suami mendampingi istri selama proses persalinan}

Hasil analisa data dari tarnskip data yang didapatkan oleh peneliti, didapatkan beberapa 
Elisia Elfina ${ }^{1}$, Ari Pristiana Dewi ${ }^{2}$, Reni Zulfitri ${ }^{3}$, Pengalaman Suami Bersuku Melayu dalam mendampingi Istri Bersalin

alasan suami bersedia mendampingi istri dan membantu proses persalinan istri dengan melawan semua rasa cemas dan takut yang dialami suami. Dalam penelitian ini, adanya 2 hal alasan suami mendampingi istri selama proses persalinan yaitu respon kesadaran dari diri suami itu sendiri dan keinginan suami untuk selalu bersama istri. Respon kesadaran dari diri suami dalam penelitian ini seperti sadar akan kewajibannya sebagai suami dan harus bertanggung jawab. Hal ini sesuai dengan ungkapan partisipan sebagai berikut:

"Ya jadi pastilah karena itu kan juga udah kewajiban seorang suami untuk mendampingi....(P1-5).

"...abang merasa itu udah menjadi kewajiban abang aja, ha jadi suami tu harus selalu setia mendampingi isrti dalam susah dan senang..."(P2-10).

"Ya itu kewajiban dan tanggung jawab saya, sebagai laki-laki kita harus bertanggung jawab kan, apalagi saya sudah berkeluarga, kemudian saya harus menjadi suami yang bertanggung jawab..."(P3-13)

“...udah merasa kewajiaban aja sebagai suami, udah itu aja. ”(P4-21)

Selain dari itu, alasan partisipan untuk mendampingi istri selama proses persalinan yaitu adanya keinginan partisipan itu untuk selalu bersama istrinya. Hal ini dapat dilihat dari ungkapan yang disampaikan oleh partisipan yang menyatakan bahwa keinginan untuk ikut menemani istri melahirkan, menyaksikan langsung dan berjanji untuk selalu bersama istri. Hal ini ada di ungkapan partisipan sebagai berikut:
“...Saya juga sudah berjanji sama istri saya bahwa saya akan ikut menemani istri saya pada saat melahirkan apa pun yang terjadi dan saya akan menyaksikan langsung bagaimana sih proses persalinan istri saya karena yang dikeluarkannya itu bukan anak dia aja tapi juga anak kami berdualah..."(P313)

"...karena apa ya? karena udah keharusan kali ya, udah terniat aja dalam hati, harus mendampingi istri apapun itu yang akan terjadi, itu janji saya sama diri saya..."(P4-21).

\section{PEMBAHASAN}

Penelitian tentang pengalaman suami bersuku Melayu dalam mendampingi istri bersalin telah mengidentifikasi 4 (empat) tema utama, yaitu : perasaan suami saat mendampingi istri bersalin, cara suami mengatasi perubahan psikologi saat mendampingi istri bersalin, dukungan suami saat mendampingi istri bersalin, alasan suami mendampingi istri selama proses persalinan.

\section{Perasaan suami saat medampingi istri bersalin}

Hasil penelitian yang ditemukan peneliti terhadap partisipan menggambarkan berbagai perasaan dalam mendampingi istri bersalin diantaranya perasaan positif dan juga perasaan negatif. Perasaan positif partisipan dalam penelitian ini yaitu senang, terharu dan bahagia saat dan setelah mendampingi istri bersalin. Partisipan dalam penelitian ini juga menyatakan perasaan negatif saat mendampingi istri bersalin yaitu cemas, takut,deg-degan dan sedih. 
Timbulnya perubahan psikologi yang dialami partisipan ini sesuai dengan pendapat yang dikemukakan oleh Nurjanah dan Indrawati (2013), yang menyatakan bahwa focus penekanan kehamilan dan persalinan adalah wanita tetapi perlu diketahui bahwa kecemasan dan ketegangan juga dialami oleh suami. Tingkat kecemasan suami saat menghadapi persalinan istri bervariasi. Menurut Margiantari, Basuki dan Ningsih (2006), kecemasan adalah kondisi yang disertai rasa takut, ketegangan dan kekhawatiran yang terjadi pada seseorang.

\section{Cara suami mengatasi perubahan} psikologi saat mendampingi istri bersalin

Partisipan dalam penelitian ini mengalami perubahan psikologi saat mendampingi istri bersalin. Cara partisipan mengatasi masalah psikologi dalam mendampingi istri bersalin adalah dengan melakukan kegiatan spiritual seperti berserah diri, berdoa dan berzikir dengan yang Maha Kuasa. Hasil penelitian ini sesuai denganwawancara yang dilakukan dengan Sekretaris Umum Lembaga Adat Melayu Provinsi Riau bapak M. Nasir Penyalai menyatakan bahwa karakteristik budaya Melayu berpedoman dengan agama Islam dan peran suami saat proses persalinan istri adalah suami sebagai penyemangat, selalu berdoa kepada Allah untuk kelancaran proses persalinan.

Kegiatan spiritual yang dilakukan oleh partisipan membuat pasrtisipan lebih tenang dan percaya bahwa hanya dengan berdoa dan meminta kepada yang Maha Kuasa yang bisa membantunya dalam mengatasi masalah yang dialaminya. Penyataan ini di perkuat dengan penelitian yang dilakukan oleh Mahmudah (2010), yang menyatakan bahwa kegiatan spiritual yang dilakukan dengan mengingat Allah akan membuat jiwa menjadi tentram, sehingga rasa takut dan cemas dapat diatasi. Kegiatan religius atau spiritual yang dilakukan akan menumbuhkan keyakinan bahwa pasti mampu melewati masalah yang dihadapi.

Partisipan juga melakukan teknik relaksasi nafas dalam untuk mengatasi masalah psikologi yang dialami dalam mendampingi istri bersalin. Kegiatan teknik relaksasi nafas dalam ini membuat partisipan menjadi tenang dalam melakukan suatu tindakan. Menurut penelitian yang dilakukan oleh Ambarwati (2015), menyatakan bahwa teknik relaksasi nafas dalam merupakan teknik yang popular dan mudah untuk dilakukan. Teknik nafas dalam ini membantu seseorang dalam mengurangi rasa cemas, takut, khawatir dan gelisah.

\section{Dukungan suami saat mendampingi istri bersalin}

Dukungan yang dilakukan partisipan dalam penelitian ini adalah memberikan dukungan fisik dan dukungan informatif. Pernyataan tersebut sesuai dengan penelitian yang dilakukan oleh Anggraeni, Sumarni dan Agustina (2014), yang menyatakan bahwa sebagian besar suami peduli terhadap persalinan yang akan dihadapi oleh istrinya sehingga membuat seorang suami mau 
Elisia Elfina ${ }^{1}$, Ari Pristiana Dewi ${ }^{2}$, Reni Zulfitri ${ }^{3}$, Pengalaman Suami Bersuku Melayu dalam mendampingi Istri Bersalin

memberikan dukungan yang besar dengan cara mendampingi istri saat bersalin. Dukungan suami adalah respon yang diberikan oleh suami terhadap istrinya yang akan bersalin. Dukungan yang diberikan berupa dukungan fisik dan dukungan emosional.

Dukungan fisik yang diberikan partisipan dalam penelitian ini berupa memegang tangan, mengelus rambut, kepala, perut dan memijit punggung istrinya. Pernyataan ini sesuai dengan penelitian yang dilakukan oleh Indrawati (2013), yang menyatakan bahwa bentuk tindakan yang dapat dilakukan suami yaitu tetap menghibur dan mendukung ibu disela kesibukkannya, memberi makan dan minum pada ibu, membantu ibu agar dapat beristirahat dengan cukup, memberikan kata-kata yang menyenangkan, lakukan pijatan ringan dibagian punggung untuk meredakan sakit punggung, menemani ibu saat pemeriksaan kehamilan.

Menurut hasil penelitian lain yang dilakukan oleh Mahmudah dan Barokah (2016), Dukungan yang diberikan oleh suami pada proses persalinan di antaranyamemberi rasa nyaman dan kenyamanan. Dukungan yang diberikan akan menyebabkan sel-sel sarafnya mengeluarkan hormon oksitosin yang reaksinya akan membuat kontraksi pada rahim.

Arifin, Kundre, dan Rompas (2015) juga menyatakan dukungan keluarga sangat diharapkan oleh seorang ibu hamil dalam menghadapi proses persalinan. Dukungan keluarga yang baik akan mengurangi stressor pada ibu sehingga proses persalinan lebih lancar tanpa menimbulkan komplikasi.

Hasil penelitian ini partisipan juga memberikan dukungan informatif. Dukungan informatif adalah dukungan yang diberikan dalam bentuk arahan, petunjuk, nasehat, saran atau pemecahan masalah. Manfaat dari dukungan ini adalah dapat menekan stressor karena informasi yang diberikan dapat menolong individu untuk mengenali dan mengatasi masalah dengan mudah (Suparni \& Astutik, 2016). Bentuk dukungan informatif yang diberikan partisipan kepada istrinya adalah memberikan motivasi berupa kata-kata semangat, melakukan kegiatan spiritual seperti berzikir dan istighfar menyebut nama Allah, karena partisipan yakin bahwa Allah lah yang bisa membantu hambanya dan hanya dialah yang tau apa yang terbaik untuk hambanya.

Keadaan ibu selama persalinan sangat dipengaruhi pemberian dukungan yang mendampingi. Dukungan akan memberikan rasa aman, rasa nyaman, dan merasa dihargai. Perhatian terhadap aspek fisik (sentuhan yang menimbulkan rasa nyaman misalnya dengan menekan daerah sacrum), aspek psikis (mengurangi kecemasan), aspek sosial (melibatkan keluarga, berkomunikasi) dan aspek spiritual (bimbingan doa/dzikir) (Hastuti, 2009).

\section{Alasan suami mendampingi istri selama proses persalinan}

Hasil penelitian ini menunjukkan bahwa partisipan memiliki alasan dalam mendampingi istri selama proses persalinan. 
Salah satu alasan partisipan dalam mendampingi istri selama proses persalinan adalah adanya kesadaran dari diri pastisipan itu sendiri seperti memiliki kewajiban untuk mendampingi istri bersalin karena anak yang dilahirkan adalah anak bersama, jauh dari keluarga salah satu alasan suami untuk bertanggungj awab kepada istri. Pernyataan ini diperkuat dengan penelitian yang dilakukan oleh Indrawati (2013), bahwa suami memiliki tanggung jawab terhadap kondisi kesehatan ibu yang akan melahirkan anaknya. Suami merupakan pasangan dari ibu bersalin yang telah terikat dalam status pernikahan secara sah dalam hukum negara dan hukum agama, sehingga suami memiliki peranan dan pengaruh lebih terhadap kesiapan ibu menjelang persalinan dan saat persalinan. Selain itu, partisipan memiliki keinginan tersendiri untuk menyaksikan langsung proses persalinan, ikut menemani istri melahirkan dan berjanji kepada istri selalu bersama merupakan alasan partisipan untuk bersedia mendampingi istri bersalin.

Penelitian dilakukan oleh Laurika, Rosalina, dan Susilo (2015) juga menyatakan bahwa suami adalah orang yang dianggap paling dekat dengan istri dan juga orang yang bertanggung jawab dalam segala hal yang terjadi terhadap istrinya, sehingga dalam setiap hal suami harus siap untuk selalu memberikan dukungan, nasehat dan mendampingi dalam beberapa peristiwa yang akan dilalui oleh istrinya. Salah satunya adalah peristiwa besar yang akan dijalani oleh seorang istri yaitu proses persalinan.

\section{SIMPULAN}

Penelitian tentang "Pengalaman suami bersuku Melayu dalam mendampingi istri bersalin" melibatkan 4 (empat) partisipan, yang dilakukan di Puskesmas Kuok Kabupaten Kampar Kecamatan Kuok. Partisipan dalam penelitian ini memiliki rentang usia 21 sampai 27 tahun dan bersuku Melayu. Seluruh partisipan mendampingi istri saat proses persalinan anak pertama dalam persalinan normal.

Hasil penelitian didapatkan 4 (empat) tema yaitu: (1) perasaan suami saat mendampingi istri bersalin yaitu perasaan positif (senang, terharu dan bahagia) dan perasaan negatif (cemas, takut, deg-degan dan sedih), (2) cara suami mengatasi perubahan psikologi saat mendampingi istri bersalin yaitu dengan melakukan teknik relaksasi nafas dalam dan kegiatan spiritual seperti berserah diri, berdoa dan berzikir dengan yang Maha Kuasa,(3) dukungan suami saat mendampingi istri bersalin terdiri dari dukungan fisik yaitu memegang tangan, mengelus rambut, kepala, perut dan memijit punggung istrinya serta dukungan informatif yaitu motivasi berupa kata-kata semangat, berzikir dan istighfar menyebut nama Allah, (4) alasan suami mendampingi istri selama proses persalinan karena adanya keinginan dan kesadaran dari diri partisipan itu sendiri seperti memiliki 
Elisia Elfina ${ }^{1}$, Ari Pristiana Dewi ${ }^{2}$, Reni Zulfitri ${ }^{3}$, Pengalaman Suami Bersuku Melayu dalam mendampingi Istri Bersalin

kewajiban dan tanggung jawab untuk mendampingi saat persalinan.

\section{SARAN}

1. Bagi Perkembangan Ilmu Keperawatan

Hasil penelitian ini diharapkan dapat memberikan wawasan dalam ilmu maternitas tentang pengalaman suami bersuku Melayu dalam mendampingi istri bersalin.

2. Bagi Puskesmas

Hasil penelitian ini diharapkan dapat memberikan informasi kepada Puskesmas tentang pengalaman suami mendampingi istri bersalin dan memberikan izin kepada para suami untuk selalu mendampingi istrinya selama proses persalinan

3. Bagi Masyarakat

Hasil penelitian ini dapat memberikan informasi dan menjadi pedoman terutama pada para suami untuk selalu mendampingi istri bersalin.

4. Bagi Peneliti Berikutnya

Hasil penelitian ini dapat dijadikan data evidence based untuk melaksanakan penelitian lebih lanjut yang berkaitan dengan pengalaman suami bersuku Melayu dalam mendampingi istri bersalin.

\section{DAFTAR PUSTAKA}

Afiyanti \& Rachmawati, I.N. (2014). Metodologi penelitian kualitatif dalam risetkeperawatan. Jakarta: PT Raja Gtavindo Persada.

Alwi, Q. (2007). Tema budaya yang melatarbelakangi perilaku ibu-ibu penduduk asli dalam pemeliharaan kehamilan dan persalinan di kabupaten Mimika. Diperoleh tanggal 24 april 20017 dari http://ejournal.litbang.kemkes.go.id.
Ambarwati, W. N. (2015). Respon dan koping perempuan Jawa selama proses melahirkan secara normal di Surakarta. Diperoleh tanggal 22 april 2017 dari http://publikasiilmiah.ums.ac.id.

Amelia, B., Elita, V., \& Dewi, Y.I. (2015).Hubungan pola asuh orang tua dengan motivasi melanjutkan pendidikan ke perguruan tinggi pada remaja di daerah pesisir Riau.Diperoleh tanggal 13 maret 2017 dari http://jom.unri.ac.id.

Anggraeni, D.S., Sumarni.,\& Agustina, E.E. (2014). Pengaruh dukungan suami dalam proses persalinan dengan nyeri persalinan di rsia bunda Arif Purwokerto.Diperoleh tanggal 20 januari 2017 dari http://JurnalBidanPrada/ojs.akbidylpp.ac.i d.

Arifin, A., Kundre.,\& Rompas, S. (2015). Hubungan dukungan keluarga dengan kecemasan ibu hamil menghadapi proses persalinan di puskesmas Budilatama kecamatan Gadung kabupaten Buol propinsi Sulawesi Tengah.Diperoleh tanggal 29 Juli 2017 dari http://ejournal.unsrat.ac.id.

Asrinah.(2010). Asuhan kebidanan masa persalinan. Yogyakarta: Graha Ilmu.

Dagun, S. M. (2002). Psikologi keluarga. Jakarta: PT Rineka Cipta.

Hastuti, B. (2009). Pengaruh dukungan suami terhadap lama persalinan kala II ibu primigravida. Diperoleh tanggal 25 Desember 2016 dari http://jogjapress.com.

Laurika, S., Rosalina.,\& Susilo, E. (2015). Hubungan dukungan suami dengan kesiapan ibu hamil menjelang proses persalinan di RSUD Tugurejo kota Semarang.Diperoleh tanggal 25 Juli 2017 dari

http://perpusnwu.web.id/karyailmiah/docu ments/4801.pdf.

Mahmudah, D. (2010). Hubungan dukungan keluarga dan religiusitas dengan kecemasan melahirkan pada ibu hamil anak pertama (primigravida).Diperoleh tanggal 27 juli 2017 dari http://repository.uinjkt.ac.id.

Mahmudah, H., \& Barokah, L. (2016).Peran suami dalam memberikan dukungan moril 
persiapan persalinan di puskesmas Pleret Bantul.Diperoleh tanggal 20 januari 2017 dari http://ejournal.stikesayaniyk.ac.id.

Margiantari E, Basuki A, Ningsih M (2012). Kecemasan terhadap kehamilan pada wanita dewasa muda yang bekerja.Diperoleh tanggal 1 agustus 2017 dari

http://www.gunadarma.ac.id/library/gradu ate/psychology.

Maryunani, A. (2010). Nyeri dalam persalinan teknik dan carapenanganannya. Jakarta: TIM.

Melalatoa, M. J. (1995). Ensiklopedi suku bangsa di Indonesia Jilid L-Z. Jakarta: CV. Eka Putra.

Nolan, M. (2015).Panduan komprehensif tentang kehamilan sehat. Yogyakarta: Golden Books.

Notoatmojo, S. (2010).Metodologi penelitian kesehatan. Jakarta: Rineka Cipta.

Noviana, R. E., \& Puspitasari, D. (2016).Kesiapan suami sebagai pendamping persalinan di puskesmas Pleret kabupaten Bantul Yogyakarta.Diperoleh pada tanggal 22 januari 2017 dari http://www.ejournal.stikesayaniyk.ac.id.

Nurasiah, A., Rukmawati, A., \& Badriah, D. L. (2012).Asuhan persalinan normal bagi bidan. Bandung: PT Refika Aditama.

Nurhalimah. (2015). Upaya dinas kebudayaan pariwisata pemuda dan olahraga dalam menyelenggarakan kegiatan bidang kebudayaan di kabupaten Nunukan. Diperoleh pada tanggal 10 maret 2017 dari http://www.ejournal.ip.fisipunmul.ac.id.

Nurjanah, S., \& Indrawati. (2013). Tingkat kecemasan suami saat menghadapi persalinan istri di rsu Asy-syifa Sambi Boyolali. Diperoleh tanggal 05 januari 2017 dari http://gaster| jurnal ilmu kesehatan, 2013 - jurnal.stikesaisyiyah.ac.id.

Polit, D. F \& Beck, C. T. (2010). Essentialsof nursing reseach: Appraising evidence for nursing practice. Philadelpia: Lippincoott Williams \& Wilkins.

Primasnia, P., Wagiyo.,\& Elisa. (2013). Hubungan pendampingan suami dengan tingkat kecemasan ibu primigravida dalam menghadapi proses persalinan kala I di rumah bersalin wilayah kota Ungaran. Diperoleh tanggal 29 Desember 2016 dari http://ejournal/ilmukeperawatan/article/view/184.

Rahman, P. L., \& Yusuf, E. A. (2012).Gambaran pola asuh orangtua pada masyarakat pesisir pantai. Diperoleh pada tanggal 10 maret 2017 dari http://jurnal.usu.ac.id/index.php/predicara/ article/download/530/293.

Rasmun.(2009). Stress, koping dan adaptasi. Jakarta: C.V Agung Seto.

Saminem. (2009). Kehamilan normal: Seri asuhan kebidanan. Jakarta: EGC.

Samin, S. M. (2008). Dari melayu ke Indonesia. Indonesia: Pustaka Pelajar.

Saryono.,\& Anggraeni, M.D. (2013). Metodologi penelitian kualitatif dan kuantitatif dalam bidang kesehatan. Yogyakarta: Nuha Medika.

Stuard, G.W. (2006). Buku saku keperawatan jiwa.EGC. Jakarta.

Sugiyono. (2012). Metode penelitian kuantitatif, kualitatif $R \& D$. Bandung : Alfabeta.

Suparni, I. E., \& Astutik, R. Y. (2016). Menopause masalah dan penanganannya. Yogyakarta: C.V Budi Utama.

Sutrisno, M., \& Putranto, H. (2005).Teoriteori kebudayaan. Yogyakarta: Kanisius

Sumarah, Yani, W., \& Nining, W. (2008).Perawatan ibu bersalin. Yogyakarta: Fitramaya. 